\title{
Microbial transformations of arsenic: perspectives for biological removal of arsenic from water
}

\author{
Lucia Cavalca*', Anna Corsini', Patrizia Zaccheo², Vincenza Andreoni' \\ \& Gerard Muyzer ${ }^{1,3}$
}

'Dipartimento di Scienze per gli Alimenti, la Nutrizione e l'Ambiente (DeFENS), Università degli Studi di Milano, Milano, Italy

2Dipartimento di Scienze Agrarie e Ambientali - Produzione, Territorio, Agroenergia (DiSAA), Università degl

Studi di Milano, Milano, Italy

${ }^{3}$ Institute for Biodiversity \& Ecosystem Dynamics, University of Amsterdam, 1090 GE Amsterdam,

The Netherlands

*Author for correspondence: lucia.cavalca@unimi.it

Arsenic is present in many environments and is released by various natural processes and anthropogenic actions. Although arsenic is recognized to cause a wide range of adverse health effects in humans, diverse bacteria can metabolize it by detoxification and energy conservation reactions. This review highlights the current understanding of the ecology, biochemistry and genomics of these bacteria, and their potential application in the treatment of arsenic-polluted water.

Arsenic is widely distributed in soil, minerals, water and biota [1]. Natural processes, as well as anthropogenic activities, are responsible for the release of arsenic into the environment. For instance, arsenic in soil comes from human inputs, such as sewage, insecticides, fertilizers, atmospheric fallout of smelters and fossil fuel combustion. Arsenic belongs to the 'nitrogen' family of the periodic table and has similar properties to nitrogen, phosphorus, antimony and bismuth. Arsenic occurs with valence states of -3 (arsine, $\mathrm{AsH}_{3}$ ), 0 (metallic, $\left.\mathrm{As}^{0}\right),+3$ (arsenite, $\mathrm{As}[\mathrm{OH}]_{3}$ ) and +5 (arsenate, $\mathrm{AsO}_{4}^{-3}$ ) depending on the environmental conditions. In soil, the first two valence states ( -3 and 0 ) occur rarely and only under very reduced conditions; moreover, these forms are often transiently present due to their volatility and high reactivity. Arsenate $(\mathrm{As}[\mathrm{V}])$ is the predominant form in soil and surface water, while arsenite (As[III]) prevails in reducing conditions in anaerobic groundwater. However, both forms exist in terrestrial and aquatic environments regardless of $\mathrm{pH}$ and redox potential (Eh), since chemical redox reactions between $A s(V)$ and $A s($ III) are relatively slow. The reduction of $A s(V)$ to $A s($ III) is involved in the solubilization of arsenic, resulting in the contamination of water supplies [2].

The concentration of arsenic in aquifers depends on the local geological characteristics and the chemical conditions. Generally, arsenic has been found at higher levels in groundwater than in surface water [3]. In groundwater, the physicochemical conditions favor the solubilization of the metalloid, especially when it is present as As(III). In surface waters, the arsenic concentrations are usually moderate $(0.2-2 \mathrm{mg} / \mathrm{l})$, although in some particular habitats, such as geothermal and mine drainage systems, levels up to $1000 \mathrm{mg} / \mathrm{l}$ can be found.

Contamination of aquifers with arsenic can be due to several processes, including anthropogenic sources, anion competition for adsorption/desorption sites on metal hydroxides, aging of iron hydroxides, complexation with dissolved organic species, release from sulfide minerals (i.e., arsenopyrite) and from phosphate fertilizers. The concentration of arsenic in aquifers is further affected by the interaction of microorganisms with minerals that may change surface properties of minerals and modify the solid-solution partition of arsenic.

\section{Arsenic \& health-related problems}

Although arsenic compounds have been used for many centuries as medicinal agents for the treatment of diseases, such as psoriasis, syphilis, rheumatosis and, more recently, cancer [4], it is considered to be one of the most toxic elements on Earth for humans. The toxicity of As(III) lies in its ability to bind to sulfhydryl groups of cysteine residues in proteins and to inactivate them. Long-term exposure to even small concentrations of inorganic arsenic can cause various health effects, such as 'arsenicosis' (Figure 1) and cancer due to DNA damage [5]. Generally, inorganic forms are more toxic than organo-arsenic species, and As(III) is more toxic than As(V). Humans are exposed to arsenic through skin contact with arsenic-polluted soil or water, and through ingestion of contaminated food (i.e., crops and seafood). However, the major threat is

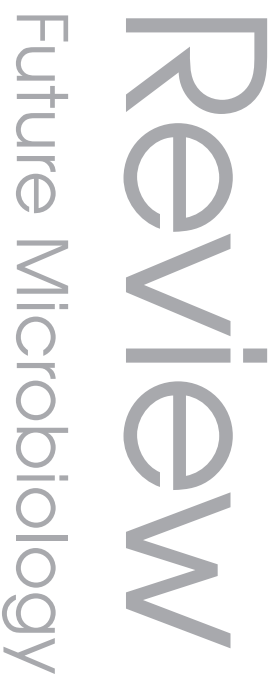

\footnotetext{
Keywords

- adsorption $=$ ARM $=$ arsenic

- arsenicosis $=$ bacteria

- bioremoval - DARP
}

\section{Future Medicine part of}




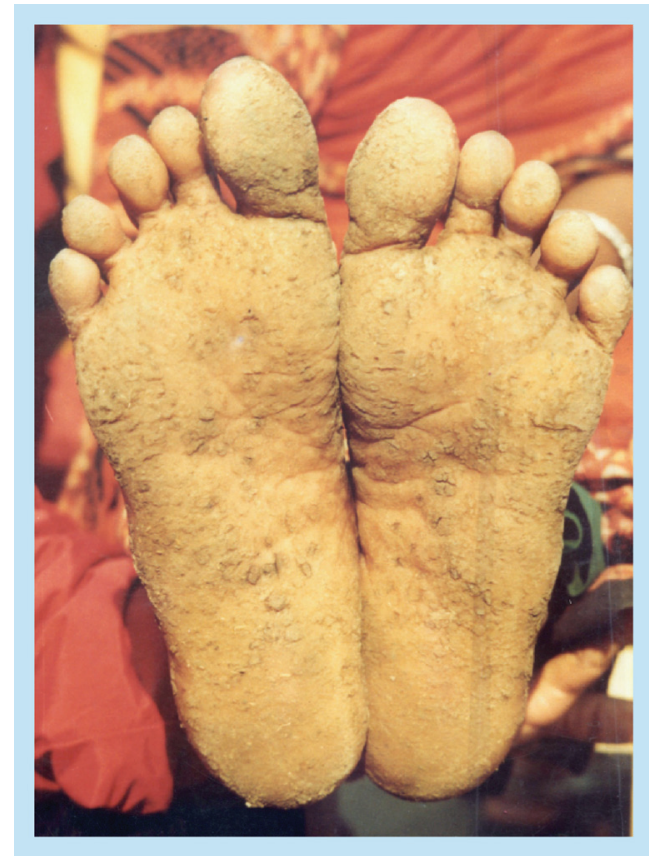

Figure 1. Example of 'arsenicosis' or arsenic poisoning. Chronic exposure to arsenic can lead to melanosis and lesions.

Reproduced with permission from [201].

contaminated drinking water [6]. Although, the WHO recommended a maximum concentration of arsenic in drinking water of $10 \mu \mathrm{g} / 1$ [7], more that 50 million people in Bangladesh and west Bengal (India) are exposed to groundwater with arsenic contents of more than $50 \mu \mathrm{g} / \mathrm{l}$. However, the problem exists in many countries, where populations are at risk of drinking water with arsenic levels above $10 \mu \mathrm{g} / \mathrm{l}$ [6]. As a consequence, there is a great demand for efficient methods to remove arsenic from drinking water.

\section{The microbiology of arsenic}

Numerous phylogenetically diverse prokaryotes are capable in transforming $\mathrm{As}(\mathrm{V})$ and $\mathrm{As}(\mathrm{III})$ in a variety of terrestrial and aquatic habitats, and at a wide range of environmental conditions (Figure 2) [8-10]. Arsenic-rich environments, such as acid mine drainage, are rich in specialized bacteria that can gain energy from redox transformation of arsenic. In particular, the isolation of phototrophic anaerobic bacteria that are able to use As(III) as an electron donor [11,12] and the characterization of ArxA as a new type of As(III) oxidase enzyme [13,14] have enabled the clarification of aspects regarding the origins of microbial arsenic metabolism and have strengthened the idea that in the Achaean era $\operatorname{As}(\mathrm{V})$ was generated in the absence of oxygen by phototrophic processes [15]. It was recently claimed that arsenic could replace phosphorous in macromolecules of a bacterial strain [16], but those findings were rapidly disclaimed by the scientific community (Box 1).

Due to the natural abundance of arsenic in the environment, many prokaryotes have evolved mechanisms to utilize arsenic for metabolic purposes or to modify the metalloid valence in order to detoxify the cell. Arsenic can enter the cell through existing transporters due to the analogy of arsenic species to other molecules [17]. $\mathrm{As}(\mathrm{V})$ enters the cell via phosphate transporters, and can then interfere with oxidative phosphorylation by replacing phosphate [18]. Entrance of As(III) into cells (at neutral $\mathrm{pH}$ ) is mediated by so-called 'aqua-glyceroporins', membrane channels for water and small nonionic solutes, such as glycerol. Prokaryotes are able to transform arsenic by oxidation or reduction [19]. Arsenotrophy, defined as the oxidation of As(III) or reduction of $\mathrm{As}(\mathrm{V})$ as part of respiratory or phototrophic processes (FIGURE 3A), requires membrane-associated proteins that transfer electrons from or to arsenic (AioBA and ArrAB, respectively). A more common phenomenon in many different bacteria is resistance to arsenic based on the presence of an 'Ars' detoxification systems (Figure 3B). In this process, $\mathrm{As}(\mathrm{V})$ is reduced intracellularly to As(III) by ArsC, a small protein of $13-16 \mathrm{kDa}$. As(III) is then extruded out of the cell by an efflux pump, namely ArsB or ACR3.

The biogeochemical cycle of arsenic, however, is often more complicated than described above, because environmental and biotic factors may critically control arsenic speciation. For instance, iron-reducing bacteria can reduce arsenic-containing iron and aluminium oxides with the release of $A s(V)$ in solution, which subsequently can be reduced to the more mobile As(III) by As(V)-reducing bacteria [20,21]. In addition, phosphorous acquisition from arsenicbearing minerals by Burkholderia fungorum was demonstrated as a mechanism of arsenic release [22]. Some microorganisms can also methylate inorganic arsenic or demethylate organic forms [19]. Moreover, a selenium- and sulfur-mediated pathway for arsenic detoxification has been proposed [23], although it remains to be further studied in detail.

\section{Microbiology \& biochemistry of As(III) oxidation}

Many heterotrophic bacteria oxidize As(III) to detoxify their immediate environment, while other bacteria are able to use As(III) as an electron donor. Chemoautotrophic As(III) oxidation has been found to occur via aerobic oxidation, 


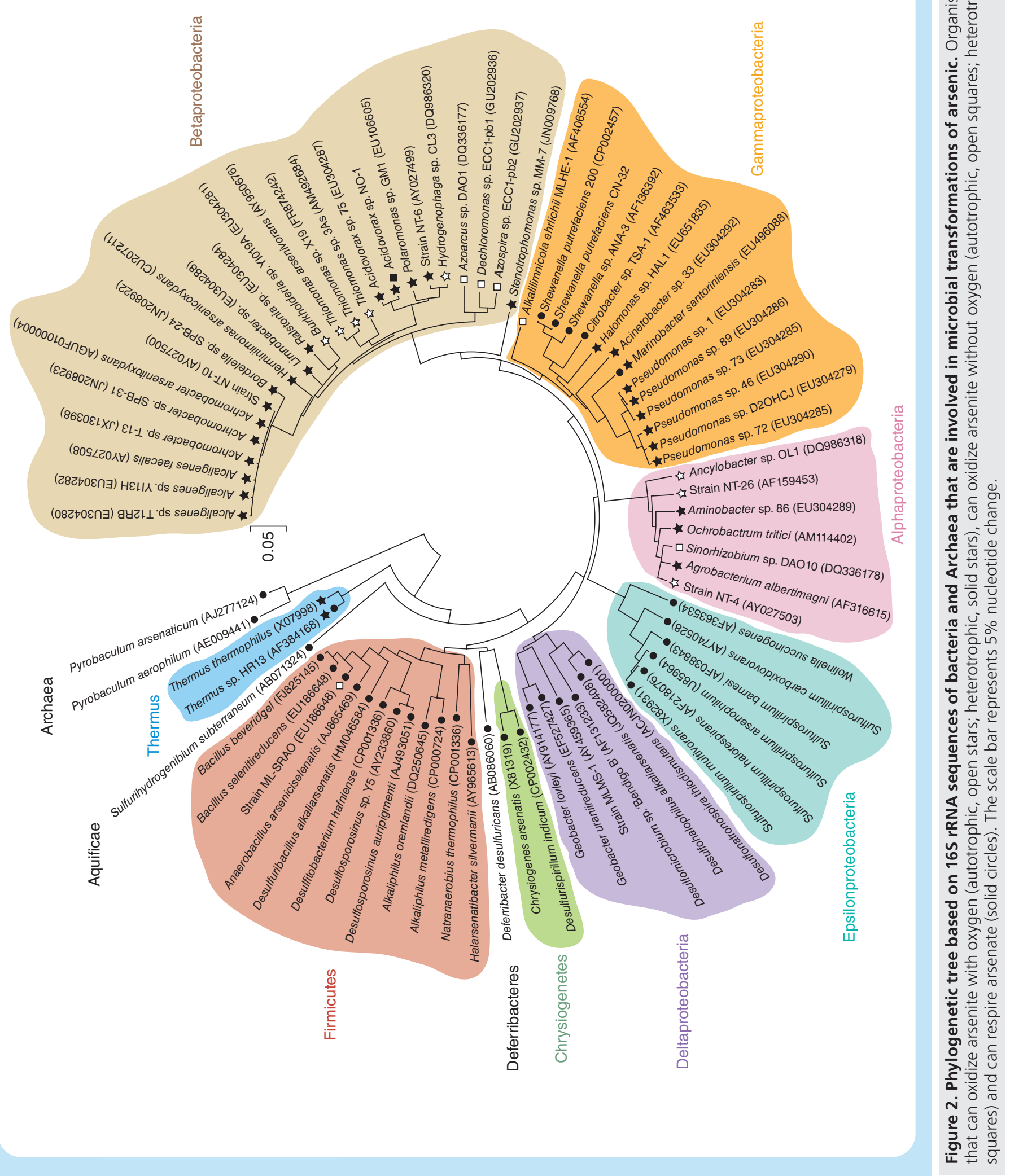




\section{Box 1. 'Arsenic life'.}

In 2011, Wolfe-Simon and coworkers published a controversial paper in Science, in which they claimed to have isolated a bacterium, strain GFAJ-1, which was able to substitute arsenic for phosphorus [16]. The authors grew the bacterium in a culture medium in which phosphate was replaced by arsenate (As[V]), and showed evidence that $\mathrm{As}(\mathrm{V})$ was incorporated into macromolecules that normally contain phosphate, such as DNA, proteins, phospholipids and small-molecular-weight metabolites, such as ATP. The publication created an avalanche of comments from other scientists criticizing the results. Subsequently, Rosen et al. wrote an interesting paper [112] in which they carefully examined and evaluated the data and conclusions of Wolfe-Simon et al. [16]. They concluded that, in principle, it would be possible that $\mathrm{As}(\mathrm{V})$ could replace phosphate in macromolecules, such as DNA, but that these molecules would be unstable and rapidly fall apart, and so 'arsenic life' would be unlikely. Recently, the group of Rosemary Redfield, one of the main criticizers of the results of Wolfe-Simon et al. [16], repeated the original experiments and could not find any $A s(V)$ in the DNA of strain GFAJ-1 [113]. The report of Erb et al., which appeared in the same issue of Science as that of Redfield's report, demonstrated that the C6 sugar arsenates detected in cell extracts of strain GFAJ-1 were formed abiotically [114]. anaerobic nitrate- and selenate-dependent respiration [8,11,24] or phototrophy (Figure 3A) [25]. By transforming the more toxic As(III) into less toxic $\mathrm{As}(\mathrm{V})$, and concomitantly gaining energy,

(A) $\quad \mathrm{As}(\mathrm{V})$

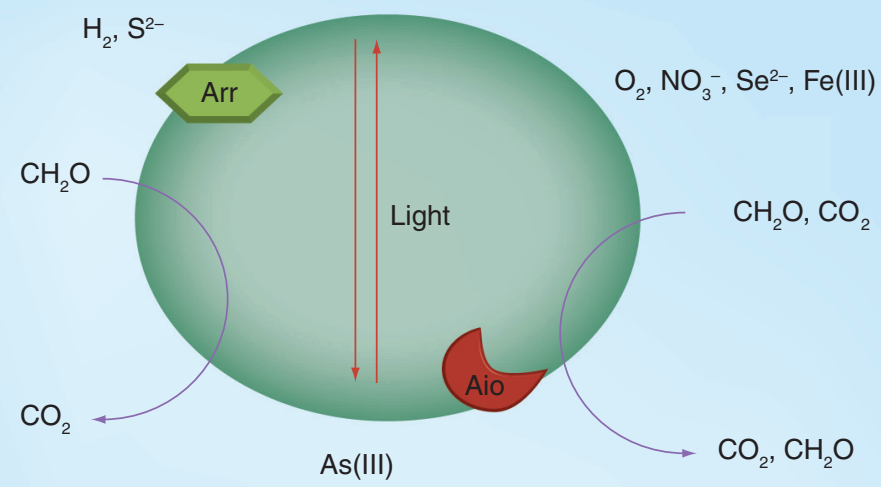

(B)

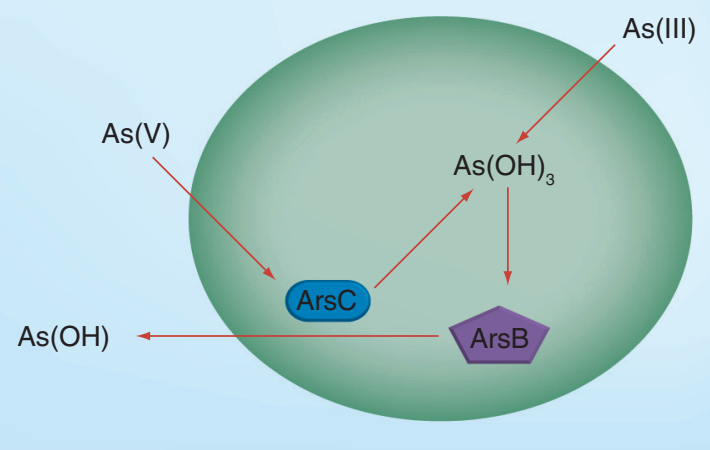

Figure 3. Different microbial transformations of arsenic. (A) As(III) oxidation (aerobic, anaerobic and anoxygenic phototrophy) and $\mathrm{As}(\mathrm{V})$ reduction as mechanisms to gain energy. (B) As $(V)$ detoxification mechanisms. As $(V)$ is reduced by $\operatorname{Ars} C$ to $A s(I I I)$, which is then extruded from the cells by the specific arsenic transporters ArsB or ACR3.

As(III): Arsenite; As(V): Arsenate. these bacteria may have an ecological advantage over other microorganisms.

As(III) oxidase, the enzyme catalyzing As(III) oxidation, has been characterized in both autotrophic and heterotrophic bacteria [26,27]. The genes encoding As(III) oxidase show a great degree of divergence, and the sequences of the As(III) oxidase genes found in autotrophic As(III) oxidizers are phylogenetically distinct from those found in heterotrophic As(III) oxidizers [28]. The name of the gene coding for As(III) oxidase has been changed over time from aox to aro, and recently it was unified as aio [29] (note that, within this article, we are using 'aio $A$ ' for the As[III] oxidase gene). Aio genes have been identified in bacteria isolated from various arsenic-rich environments [30]. Bacteria carrying aio belong to Alpha-, Betaand Gamma-proteobacteria [28,31-34] as well as to Deinococcus-Thermus (Figure 2). Homologs of As(III) oxidase have also been identified in the genomes of the Crenarcheota Aeropyrum pernix and Sulfolobus tokodaii [35].

As(III) oxidase contains two heterologous subunits: a large catalytic subunit (AioA) that contains the molybdenum cofactor together with a $3 \mathrm{Fe}-4 \mathrm{~S}$ cluster, and a small subunit (AioB) that contains a Rieske $2 \mathrm{Fe}-2 \mathrm{~S}$ cluster [36]. The inducible As(III) oxidation system of Ralstonia sp. 22 possesses a soluble c554 cytochrome as a second electron acceptor, in addition to the heterodimeric membrane-associated enzyme [27]. Interestingly, the As(III) oxidase activity in Ralstonia sp. 22 was found to be inhibited by sulfite and sulfide, thus supporting the idea that sulfur and arsenic metabolism are tightly linked. To date, only four species (Agrobacterium tumefaciens 5A, Thiomonas sp. 3As, Herminiimonas arsenicoxydans and Ochrobactrum tritici) have been reported to have a cytochrome $\mathrm{C}$ gene cotranscribed with the aio $B A$ genes $[37-40]$.

The enzymology of AioA has some features in common with the $A s(V)$ respiratory reductase, ArrA. A novel type of As(III) oxidase gene $(\operatorname{arx} A)$ in the genome of the chemolithotrophic organism Alkalilimnicola ehrlichii MLHE-1, isolated from the halo-alkaline Mono Lake (CA, USA) [11], showed a higher sequence similarity to $\operatorname{arr} A$ than to aioA [13]. ArxA of MLHE-1 is implicated in reversible As(III) oxidation and $\mathrm{As}(\mathrm{V})$ reduction in vitro. MLHE-1 can couple As(III) oxidation with nitrate reduction [11]. On the basis of comparative sequence analysis, ArrA and AioA form distinct phylogenetic clades within the dimethyl sulfoxide reductase family 
of proteins, which probably evolved separately from a common ancestor [41]. Recently, an arx operon similar to that of MLHE-1 was identified in the genome of Ectothiorhodospira sp. strain PHS-1 [14]. This is a photosynthetic purple sulfur bacterium isolated from hydrothermal waters of the halo-alkaline Mono Lake and it is able to use As(III) as an electron donor in anoxygenic phototrophy [12]. In addition to these, strain ML-SRAO has been isolated from Mono Lake, which is able to oxidize As(III) anaerobically, while reducing selenite [42]. This strain is different from MLHE-1, because it cannot grow autotrophically and can only grow heterotrophically on lactate in the presence of $A s(V)$ as the electron acceptor. The lack of amplification of the As(III) oxidase gene and the positive amplification of the $\operatorname{arr} A$ gene from strain ML-SRAO is indicative that this ArrA, similarly to that of MLHE-1, acts as an oxidoreductase, although further research is necessary to confirm this finding.

This new mechanism of As(III) oxidation enables biological oxidation of arsenic in other environments including other soda lakes, hydrothermal vents or metal-polluted soils and waters. Comparison between the sequences of As(III) oxidase and those of other proteins involved in electron transfer reactions has suggested that this enzyme might be a very ancient protein [35]. Colonization of primeval anoxic, arsenic-rich environments by bacteria using $\mathrm{As}$ (III) as an electron source and transforming it into the less toxic $\mathrm{As}(\mathrm{V})$ may have resulted in a partial detoxification of these inhospitable environments, making it possible for other microorganisms to survive and proliferate.

\section{Microbiology \& biochemistry of As(V) reduction}

Some microorganisms can use $\mathrm{As}(\mathrm{V})$ as an electron acceptor in anaerobic respiration (dissimilatory $\mathrm{As}[\mathrm{V}]$-respiring prokaryotes [DARPs]) or can reduce $\mathrm{As}(\mathrm{V})$ to $\mathrm{As}(\mathrm{III})$ as a means of detoxification (As[V]-resistant microbes [ARMs]). ARMs were discovered first, and their resistance mechanisms encoded by the ars operon have been extensively studied. The configuration of the operon is different for different strains [19]; the most simple configuration $(\operatorname{ars} R B C)$ consists of the regulatory protein ArsR, which possesses an As(III)-specific binding site, the $\mathrm{As}(\mathrm{V})$ reductase $\mathrm{Ars} \mathrm{C}$ and the As(III) efflux pump ArsB (Figure 4). ArsC mediates the reduction of $\mathrm{As}(\mathrm{V})$ with glutaredoxin, glutathione or thioredoxin. This detoxification system requires energy in the form of ATP [43]. Ars $\mathrm{C}$ is localized in the cytoplasm and it can only reduce $\mathrm{As}(\mathrm{V})$ that has entered the cells, whereas it is unable to reduce $\mathrm{As}(\mathrm{V})$ adsorbed to $\mathrm{Fe}(\mathrm{III})$ [44]. Two families of transmembrane efflux pumps are known: the ArsB and the ACR3 families. The ACR3 type is more widespread in nature, being found in bacteria, animals and plants, while ArsB is only present in bacteria [45]. A second operon configuration (arsRDABC) contains the additional presence of the ATPase ArsA, which provides energy for ArsB, which is a chaperone for arsenic efflux through ArsAB. In a third operon configuration, the ars genes are arranged in two operons ( $\operatorname{ars} R C$ and $\operatorname{ars} B H$ ) transcribed in opposite directions. The function of $\mathrm{ArsH}$ is not completely clear: it is present in almost all of the Gram-negative bacteria that carry an ars operon and it is absent in Gram-positive bacteria. It was demonstrated that, in Ochrobactrum tritici strain SCII24T, ars $H$ confers the ability to grow at high arsenic concentrations [46].

While ARMs are widespread in all of the different bacterial phyla, DARPs are found in the Firmicutes, Gamma-, Delta- and Epsilonproteobacteria, Aquificae, Deferribacteres, Chryosiogenetes and in the Archaea (Figure 2). In the case of DARPs, the key enzyme is an $\mathrm{As}(\mathrm{V})$ reductase, ArrA. The arr operon comprises two genes, $\operatorname{arr} A$ and $\operatorname{arr} B$, encoding large and small subunits, respectively [47]. A third component, $\operatorname{arr} C$, has been retrieved in some organisms (i.e., Desulfitobacterium hafniense, Alkaliphilus metalliredigens and Wollinella succinogenes). An additional $\operatorname{arr} D$, coding for a chaperone, is present in Alkaliphilus oremlandii, Bacillus selenitireducens MLS10, strain MLMS-1, Geobacter lovleyi, D. hafniense and Halarsenatibacter silvermanii [48]. The expression and activity of the respiratory $\mathrm{As}(\mathrm{V})$ reductase were assessed for Shewanella sp. strain ANA-3 [49]. Arr is a heterodimer periplasmic protein that is functional only when the two subunits ArrA and ArrB are expressed together. Arr of strain ANA-3 is expressed at the beginning of the exponential growth phase and expression persists throughout the stationary phase, when it is released from the cell. Electron acceptors, such as antimonite, nitrate, selenate and sulfur, do not switch on the activity of the protein. Specific induction of ArrA in the presence of $A s(V)$ and acetate was recently demonstrated for the $\mathrm{Fe}$ (III)-reducing G. lovleyi [50], demonstrating the role of such bacteria in the release of arsenic from groundwater sediments. Microorganisms that are able 


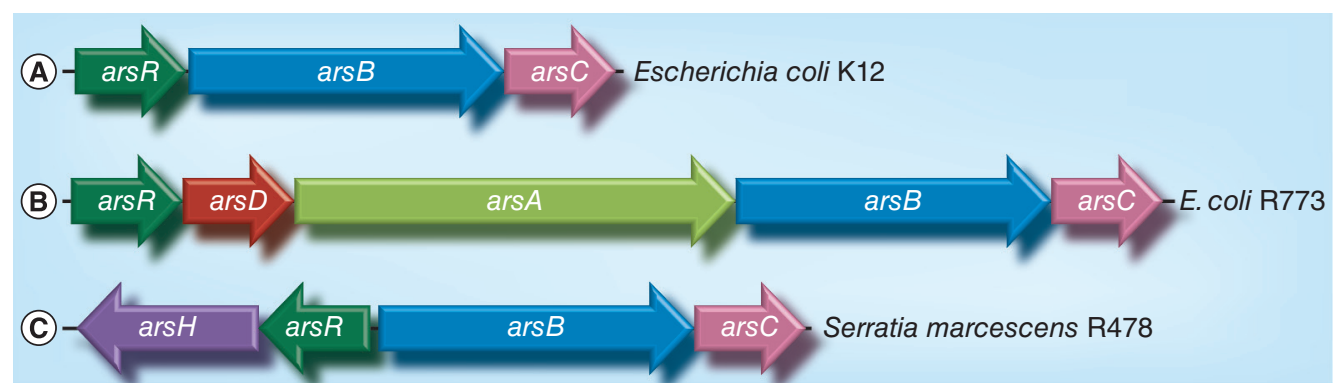

Figure 4. Organization of genes involved in arsenic resistance. (A) Three-gene operon consisting of $\operatorname{ars} R B C$, such as that which is present in the genome of Escherichia coli K12. (B) Fivegene operon consisting of $\operatorname{arSRDABC}$, such as that which is present on a plasmid of $E$. coli R733. (C) Four-gene operon consisting of $\operatorname{ar} H \mathrm{HBC}$, such as that which is present on a plasmid of Serratia marcescens.

Adapted with permission from [43].

to respire $\mathrm{As}(\mathrm{V})$ often respire selenium [51]. Extremophiles from soda lakes have also been characterized recently, and they can use a different range of electron acceptors. Desulfuribacillus alkaliarsenatis can reduce $\mathrm{As}(\mathrm{V})$ and elemental sulfur completely, and thiosulfate incompletely [52]. D. alkaliarsenatis was shown to preferentially respire As $(\mathrm{V})$ over sulfate [53]. Anaerobic bacteria can display $\mathrm{As}(\mathrm{V})$ reduction abilities both as $\mathrm{As}(\mathrm{V})$-respiring heterotrophs gaining energy from the oxidation of small organic molecules [54] or aromatic compounds [55], and as chemolithoautotrophs gaining energy from hydrogen and sulfide [15].

ArrA, characterized by a molybdenum center and $(\mathrm{Fe}-\mathrm{S})$ clusters, is a biochemically reversible enzyme [56], acting as an oxidase or reductase depending on its electron potential and the constituents of the electron transfer chain. It performs as an As(III) oxidase in the chemolithoautotroph A. ebrlichii, which couples the oxidation of As(III) to the reduction of nitrate and is incapable of respiring $\mathrm{As}(\mathrm{V})$ [11]. The same reversible ability was also demonstrated for two $\mathrm{As}(\mathrm{V})$ respiring bacteria, Alkaliphilus oremlandii [24] and Shewanella sp. ANA-3 [57]. The expression of both reductive and oxidative activities in one and the same organism is quite rare. $\mathrm{As}(\mathrm{V})$ reductase activity was evidenced in the As(III)-oxidizing strain A. tumefaciens when the strain lost As(III) oxidation capability [37]. Among DARPs, As(III) oxidase activity has been observed in Marinobacter santoriniensis [58], Thermus sp. HR13 [59] and in strain ML-SRAO [42].

Differently from ArsC, ArrA can reduce either soluble or adsorbed $\mathrm{As}(\mathrm{V})$. The first evidence for this came from the study of Zobrist et al., in which Sulfurospirillum barnesii strain SES-3, capable of anaerobic respiration of either $\mathrm{Fe}$ (III) and $\mathrm{As}(\mathrm{V})$, was demonstrated to be able to reduce $\mathrm{As}(\mathrm{V})$ when the oxyanion was dissolved in solution and when adsorbed onto ferrihydrite and aluminum hydroxide [60]. These experiments also demonstrated that the $\mathrm{As}(\mathrm{V})$ reduction was not linked to the reductive dissolution of the adsorbent mineral phase. In Shewanella sp. ANA-3, which possesses both ArsC and ArrA [57], only ArrA reduced $A s(V)$ in the presence of $A s(V)$-saturated ferric (hydr)oxide [61]. The environmental implication in the arsenic cycle is very different: the release of arsenic from sediments to groundwater is mainly due to reductive reactions of DARPs and $\mathrm{Fe}$ (III) reducers instead to those of ARMs. The former are involved in a process of mineral dissolution and bioreduction of adsorbed $\mathrm{As}(\mathrm{V})$ in aquifer materials, whereby DARPs are fueled by the oxidation of organic substrates, passing their electrons either to $\mathrm{As}(\mathrm{V})$ or $\mathrm{Fe}(\mathrm{III})[62,63]$.

\section{Detection \& distribution of arsenic bacteria}

Apart from colorimetric [64] and cultivationbased methods, such as the most-probablenumber approach [65], molecular markers have been used to detect and identify arsenic bacteria in environmental samples. The most used marker is the 16S rRNA gene (see Table 1 for an overview), although this gene is not specific for arsenic bacteria, and so other bacteria present in the samples are detected as well.

Molecular markers involved in arsenic metabolism, however, are more efficient in detecting arsenic bacteria and in studying their diversity and distribution (Taвre 1). For example, Inskeep and coworkers were the first to develop and apply a specific PCR for As(III) oxidase genes (aioAlaroA/asoA/aoxB) [66]. With this PCR technique, they successfully amplified aioA-like sequences from different arsenic-contaminated environments, including soils, sediments and hot spring microbial mats. In addition, they were 
Table 1. Overview of the different molecular markers used to detect arsenic bacteria.

\begin{tabular}{|c|c|c|c|}
\hline Molecular marker & Method & Environment & Ref. \\
\hline \multirow[t]{11}{*}{ 16S rRNA } & PCR, DGGE, cloning, sequencing & Groundwater storage tank & [115] \\
\hline & Pyrosequencing & Soil & [70] \\
\hline & $P C R$, cloning, sequencing & Creek sediments & [89] \\
\hline & $\mathrm{PCR}$, cloning, sequencing & Marine hydrothermal sediments & [9] \\
\hline & PCR, DGGE, sequencing & Tin mine soil & [116] \\
\hline & PCR, DGGE, cloning, sequencing & Deep-sea sediments & [117] \\
\hline & PCR, DGGE, cloning, sequencing & Tube well water & [118] \\
\hline & $P C R$, cloning, sequencing & Hot springs & [119] \\
\hline & PCR, cloning, sequencing & Mine sediments & {$[77]$} \\
\hline & PCR, DGGE, cloning, sequencing & Hot springs & [120] \\
\hline & PCR, T-RFLP, cloning, sequencing & Acid mine drainage & [121] \\
\hline \multirow[t]{3}{*}{ aioA } & PCR, cloning, sequencing & Soils, sediments, hot springs & {$[66,67]$} \\
\hline & $P C R, D G G E$, sequencing, $q P C R$ & Surface water and groundwater & {$[68]$} \\
\hline & $P C R$, cloning, sequencing & Creek sediments & [69] \\
\hline \multirow[t]{2}{*}{$\operatorname{ars} B$} & $P C R$, sequencing & Isolates & {$[30,45]$} \\
\hline & PCR, cloning, sequencing & Soil & [70] \\
\hline \multirow[t]{2}{*}{$\operatorname{ars} \mathrm{C}$} & $\mathrm{qPCR}$ & Bioreactor and mine soil & [71] \\
\hline & $P C R$, sequencing & Isolates & [72] \\
\hline \multirow[t]{2}{*}{$A C R 3$} & $P C R$, sequencing & Isolates & {$[30,45]$} \\
\hline & PCR, cloning, sequencing & Soil & [70] \\
\hline \multirow[t]{4}{*}{$\operatorname{arr} A$} & PCR, DGGE, sequencing & Soda lake sediments & {$[73,74]$} \\
\hline & PCR, cloning, sequencing & Estuary sediments & [75] \\
\hline & PCR, cloning, sequencing & Aquifer sediments & [20] \\
\hline & RT-PCR, cloning, sequencing & Groundwater & [50] \\
\hline $\operatorname{ar} \times A$ & PCR, cloning, sequencing & Sediments & [14] \\
\hline Functional genes & GeoChip 3.0 & Soil & [76] \\
\hline
\end{tabular}

able to detect the expression of As(III) oxidase in some of these environments. In a subsequent paper, the authors redesigned the primers for aioA-like sequences, and so could detect additional sequences associated with members of the Aquificales in various hot springs of Yellowstone National Park (WY, USA) [67]. Quéméneur et al. used denaturing gradient gel electrophoresis and quantitative real-time PCR of aio $A$ genes to study the diversity and abundance of As(III)oxidizing bacteria along a gradient of arsenic pollution in waters of the Upper Isle River Basin in France [68]. They observed different denaturing gradient gel electrophoresis profiles for different samples and found the highest number of aio $A$ genes in the most arsenic-polluted surface waters. Heinrich-Salmeron et al. used the aio $A$ gene to investigate the diversity and distribution of As(III) oxidizers in sediments of a creek that received water from a mine [69]. The authors could amplify aio $A$ from DNA of different bacterial strains isolated from the sediment, as well as from DNA extracted from the sediment directly. By comparative analysis of the 16S rRNA and aioA sequences of the isolates, the authors concluded that various bacteria obtained their aioA gene by horizontal gene transfer, indicating that aio $A$ is not a good phylogenetic marker. A molecular survey of anaerobic As(III) oxidase gene $\operatorname{arx} A$ was recently performed on sediments from the different sites of Mono Lake and Hot Creek (CA, USA) using degenerate PCR primers [14]. The authors were able to detect $\operatorname{arx} A$ genes in the top sediment layers, possibly 
hosting photosynthetic As(III) oxidizers. Most sequences were similar to those of $A$. ehrlichii MLHE-1, Ectothiorhodospira sp. PHS1 and of Halorhodospira halophila SL1.

Other specific markers are genes encoding As(III) transporters (or efflux pumps), such the ars and $A C R$ genes. Achour and coworkers designed primers for $\operatorname{ars} B, A R C 3(1)$ and $A R C 3(2)$ and studied the diversity of arsenicresistant bacteria isolated from soil [45]. In another study, Cai et al. used the same primers, as well as primers for the As(III) oxidase gene aio $A$, to study the diversity and distribution of $\mathrm{As}(\mathrm{III})$-resistant bacteria isolated from arsenic-contaminated soil [30]. They found that bacteria containing genes for both As(III) oxidation $($ aio $A)$ and $A s(\mathrm{III})$ transportation $(A R C 3$ or $\operatorname{ars} B$ ) could tolerate higher concentrations of arsenic than bacteria with genes for As(III) transporters only. In addition, they found a higher diversity of arsenic-resistant bacteria in soils that had a long-term exposure to high concentrations of arsenic, which was probably caused by horizontal gene transfer of $A R C 3(2)$ and $\operatorname{ars} B$. Sheik and coworkers found the opposite for the diversity of $A R C 3$ (i.e., a decreasing diversity of $A R C 3$ with an increase in arsenic pollution), although some of the samples were also contaminated with chromium [70]. They found a similar result as Cai et al. for the horizontal transfer of arsenic-resistance genes in isolates [30].

In addition to the application of the molecular markers mentioned above, the gene encoding $\operatorname{As}(\mathrm{V})$ reductase $(\operatorname{ars} C)$ was also used for the detection and diversity analysis of arsenicresistant bacteria. Sun and coworkers developed a quantitative real-time PCR assay to quantify the abundance of $\operatorname{ars} C$ genes in environmental samples contaminated with arsenic [71]. Kaur et al. used the same molecular marker to study the diversity of $\operatorname{ars} C$ genes in arsenic-resistant Escherichia coli strains [72].

Finally, the $\operatorname{arr} A$ gene, encoding the $\alpha$-subunit of the $\mathrm{As}(\mathrm{V})$ respiratory reductase, was used as a molecular marker to detect and monitor uncultured DARPs in sediments of Mono Lake and Searles Lake [73,74], Chesapeake Bay [75], in aquifer sediments [20] and in groundwater during in situ uranium bioremediation [50].

Xiong and coworkers used GeoChip 3.0 to study the microbial communities in arseniccontaminated soil from the rhizosphere of Pteris vittata, the Chinese brake fern, which can accumulate large amounts of arsenic [76]. GeoChip 3.0 is a DNA microarray with a high density of oligonucleotide probes that are specific for 2594 functional genes [77]. By using this microarray, the authors found that the microbial diversity was reduced in arsenic-contaminated soil compared with noncontaminated soil, and that genes for arsenic resistance, sulfur reduction, phosphorus utilization and denitrification were different between soil samples from the rhizosphere and non-rhizosphere, and between contaminated and noncontaminated soils.

Apart from the detection of arsenic bacteria, bacteria equipped with arsenic genes have been used as biosensors to detect the presence of arsenic in the environment $[78,79]$.

\section{'Arsenomics'}

Over the last 5 years, the genomes of many different arsenic bacteria were sequenced. Muller and coworkers sequenced the genome of $H$. arsenicoxydans [39], a heterotrophic bacterium isolated from a plant treating industrial waste water contaminated with arsenic, copper, lead and silver [80]. The authors not only found genes that were directly involved in detoxification of arsenic, such as genes involved in the oxidation (aioA) and extrusion (ars) of As(III), but also genes involved in chemotaxis and motility, genes necessary to sense arsenic and to move towards it, genes encoding the production of exopolysaccharides to bind arsenic and genes involved in DNA repair to heal the damage caused by As(III). A few years later, the same research group sequenced the genome of Thiomonas sp. 3As [81], a facultative chemolithoautotroph, which was isolated from acid mine drainage containing high concentrations of arsenic. The authors reconstructed the different metabolic pathways, including that of arsenic metabolism, which was encoded by genes for arsenic resistance $(\operatorname{ars} C, \operatorname{ars} A, \operatorname{ars} B$ and arsR) and As(III) oxidation (aioBA). Comparative analysis of the genomes of eight different Thiomonas strains showed that the evolution of the Thiomonas genome resulted from the loss and gain of so-called 'genomic islands', which were influenced by the extreme conditions of the habitat. $\mathrm{Li}$ and coworkers sequenced the genome of Achromobacter arsenitoxydans SY8, which was isolated from arsenic-contaminated soil of a pig farm, and could oxidize As(III) to $\mathrm{As}(\mathrm{V})$ very efficiently [82]. The genome contained an 'arsenic island' with genes for arsenic resistance (ars operon), As(III) oxidation (aio operon) and phosphate uptake (pst operon). In addition, genes encoding metal transporters were present. The same research group 
also sequenced the genomes of Halomonas sp. strain HAL1 [83] and Acidovorax sp. strain NO1 [21], which were both isolated from arseniccontaminated soil of a gold mine, and found similar operons to $A$. arsenitoxydans. Hao et al. sequenced the genome of the As(III)-oxidizing strain $A$. tumefaciens strain $5 \mathrm{~A}$ and detected an aio operon involved in As(III)-oxidation, of which the expression was regulated by a twocomponent signal transduction system and by quorum sensing [84].

To study the expression of different genes in bacteria when growing with arsenic, Srivastava et al. performed comparative proteome analysis of Staphylococcus sp. strain NBRIEAG-8, which was isolated from arsenic-contaminated rhizospheric soil of west Bengal, India [85]. They compared the total protein profiles of cells grown with and without $A s(V)$ and found 14 proteins that were significantly up- or down-regulated. Proteomic analysis showed that these proteins were involved in protein synthesis, signaling, phosphate transport, energy generation and carbon metabolism. Bryan et al. used proteomics to study carbon and arsenic metabolism in five Thiomonas strains [86]. They found that in the presence of arsenic, genes involved in arsenic metabolism and carbon assimilation were both expressed in $T$. arsenivorans, but that in Thiomonas sp. 3As, the genes in carbon assimilation were repressed, indicating the strong linkage between these two processes.

The same research group also used microarrays to study gene expression in $H$. arsenicoxydans during arsenic stress [87]. They found a rapid induction (i.e., after $15 \mathrm{~min}$ ) of genes involved in general stress, while genes that were specific for arsenic were induced only after $8 \mathrm{~h}$.

Apart from sequencing the genomes of pure cultures of arsenic bacteria, the metagenomes of microbial communities from arsenic-contaminated environments were also sequenced and characterized [88-90]. By using metagenomics and metaproteomics, Bertin et al. could infer the structure and function of a microbial community in acid mine drainage that was highly contaminated with arsenic [90]. They could discriminate seven organisms: five were affiliated to Thiomonas, Acidithiobacillus, Acidobacteria, Thiobacillus and Gallionella, and two organisms named 'Candidatus Fodinabacter communificans' were attributed to a new phylum. By using this combined metagenomics and metaproteomics approach, the authors could deduce the different metabolic pathways that were present and active in these microorganisms and could present a conceptual model of the community consisting of autotrophic, mixotrophic and heterotrophic microorganisms.

\section{Arsenic removal from waters: the biological step}

Many technologies are now available for arsenic removal that have been specifically developed for industrial-scale plants; among these, the best available technologies include anion exchange, activated alumina, reverse osmosis, modified coagulation/filtration, modified lime softening and oxidation/filtration [91]. It is difficult to compare the costs of various treatment technologies as the efficiency depends on different parameters (i.e., maximum contaminant level, co-occurrence of solutes, quality of the source water, operations and maintenance expenditures, permission requirements and wastedisposal issues). However, Mondal et al. made a cost comparison among the most used technologies for arsenic removal, considering the daily cost of the treatment of 1 million gallons water of the same quality [91]. They concluded that coagulation/filtration and lime-softening techniques are the cheapest (treatment cost $<$ US $\$ 20,000$ ), but with the lowest efficiency ( $<90 \%$ of arsenic removal). Among the removal processes with the highest efficiency ( $>95 \%$ of arsenic removal), those using sorbents such as activated alumina turned out to be the cheapest (treatment cost $<\mathrm{US} \$ 85,000)$ ). Other commonly used sorbents with high arsenic removal efficiency ( $>95 \%)$ are based on iron compounds [92]. These sorbents are not regenerable and their adoption remains expensive for poor countries. For this reason, research for cost-effective and efficient alternative sorbents (or surface-coated sorbents) is still in progress [91].

Moreover, any effective treatment of arseniccontaminated water has to remove both As(III) and $\mathrm{As}(\mathrm{V})$ forms, but sometimes classical technologies are not efficient enough in the removal of As(III). For example, adsorbents used in the most common treatment technologies often require preoxidation of $A s(\mathrm{III})$ to $\mathrm{As}(\mathrm{V})$, as $\mathrm{As}(\mathrm{III})$ is more difficult to remove by the positively charged surfaces of adsorbents. This is a crucial point, because the new arsenic drinking water standard imposes a reduction of arsenic to $10 \mu \mathrm{g} / \mathrm{l}$ and, consequently, there is a dramatic demand for oxidation technologies that effectively convert $\mathrm{As}(\mathrm{III})$ into $\mathrm{As}(\mathrm{V})$ prior to its removal.

Biological water treatment methods are considered to be a suitable approach to overcome these problems and they have attracted considerable 
research interest over recent years. Removal of arsenic can be performed by using natural consortia, pure cultures of arsenic resistant bacteria or iron- and manganese-oxidizing bacteria that can transform and/or capture arsenic forms indirectly (Table 2).

An innovative technology for arsenic removal uses biocolumn reactors consisting of immobilized bacterial cells capable of arsenic adsorption. A novel, cost-effective biocomposite - granules of cement coated with cysts of Azotobacter - has been used for arsenic removal from drinking water [93]. This biocomposite removed approximately $96 \%$ of arsenic, probably due to the presence of polysaccharides and other macromolecules that interact with arsenic. Mondal et al. utilized cells of Ralstonia eutropha immobilized on a granular, activated carbon bed in a column reactor to remove arsenic from a synthetic industrial effluent [94]. After an initial stage of adaptation and biofilm formation, the cells were able to capture both As(III) and As(V).

Bioremoval processes involve both the direct adsorption of arsenic by microbial biomass and the adsorption and coprecipitation of arsenic with biogenic iron or manganese hydroxides [95]. The application of biological processes for the oxidation and removal of dissolved iron and manganese has been proposed as another efficient means for the simultaneous removal of arsenic and iron [96]. The main product of biological oxidation of iron is usually a mixture of poorly ordered iron oxides with significant amounts of organic matter. Arsenic can be removed by direct adsorption or by coprecipitation on the preformed biogenic iron oxides, whereas there is also an indication of As(III) oxidation by iron-oxidizing bacteria, leading to improved overall removal efficiency. Katsoyiannis and Zouboulis investigated the removal of arsenic during biological iron oxidation in a fixed-bed upflow filtration unit containing polystyrene beads [97]. They reported that iron oxides were deposited in the filter medium, along with the iron-oxidizing bacteria Gallionella ferruginea and Leptothrix ochracea, offering a favorable environment for arsenic to be adsorbed and consequently removed from the aqueous streams. The authors also demonstrated that, under the experimental conditions used, As(III) was oxidized by microorganisms that colonized the filter medium, contributing to an overall increase of arsenic removal (up to 95\%), even when initial arsenic concentrations were up to $200 \mu \mathrm{g} / \mathrm{l}$.

$\mathrm{As}(\mathrm{V})$ reducers were thought to increase the element's mobility until the discovery of Desulfosporosinus auripigmenti, an As(V)- and sulfur-respiring microorganism that precipitates arsenic trisulfide $\left(\mathrm{As}_{2} \mathrm{~S}_{3}\right)$, leading to the biogeogenic formation of auripigment [98]. More recently, photoactive As-S ('realgar') nanotubes have been shown to be produced by Shewanella sp. strain $\mathrm{HN}-41$, an anaerobic bacterium that uses $\mathrm{S}_{2} \mathrm{O}_{3}{ }^{2-}$ as an electron acceptor and lactate as an electron donor, and concomitantly reduces $\mathrm{As}(\mathrm{V})$ to As(III) for detoxification purposes [99].

Besides bioremoval of arsenic and biogeogenic mineral formation, bacterial oxidation of As(III) to $\mathrm{As}(\mathrm{V})$ is a promising approach to treat contaminated water instead of using conventional oxidants (i.e., potassium permanganate, chlorine, ozone, hydrogen peroxide or manganese oxides).

In recent years, several studies have been conducted to assess the As(III) oxidation efficiency of different As(III)-oxidizing bacteria attached on immobilized materials. Ito et al. developed a bioreactor with Ensifer adhaerens cells immobilized on polyvinyl alcohol gel droplets to study the As(III) oxidation efficiency of the strain in synthetic groundwater containing $1 \mathrm{mg} / \mathrm{l}$ of As(III) [100]. The authors demonstrated that As(III) was oxidized to As(V) over the complete time course of the experiment, resulting in a removal efficiency of $90 \%$.

In a paper by Bag et al., a packed-bed column of a continuous flow reactor with Rhodococcus equi cells immobilized on rice husks was used both to investigate the As(III)-oxidizing performance of the reactor, and also to develop a deterministic mathematical model for explaining the trend of arsenic removal [101]. Simulated arsenic-laden water and naturally occurring water with arsenic concentrations ranging from 50 to $100 \mathrm{ppb}$ were used. The cells were able to detoxify the simulated arsenic water in the tested range and a maximum As(III) removal efficiency value of $95 \%$ was obtained in these processes. Finally, the authors stated that the simulated results were satisfactorily comparable to the experimental results. Similarly, Dastidar and Wang developed a modeling analysis of autotrophic As(III) oxidation in a biofilm reactor using T. arsenivorans strain b6 under different As(III) concentrations (500-4000 mg/l) [102]. The authors concluded that the As(III) oxidation efficiency rate of the reactor ranges from 48.2 to 99.3\% and the observed and predicted As(III) flux data exhibited good agreement.

As(III) oxidation can not only be performed by pure cultures, but also by bacterial consortia, as reported by several authors [103,104]. In both of these papers, the authors investigated the 


\begin{tabular}{|c|c|c|c|c|c|c|c|c|c|c|c|c|c|}
\hline & I & $\bar{\alpha}$ & Б & 合 & $\overline{\mathbb{Z}}$ & & $\stackrel{\Xi}{\Xi}$ & $\underset{\Xi}{\stackrel{F}{\Xi}}$ & & $\bar{\Xi}$ & $\stackrel{\bar{g}}{g}$ & & $\stackrel{\varrho}{\Xi}$ \\
\hline & 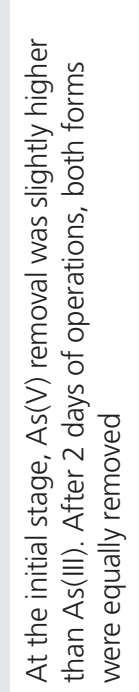 & 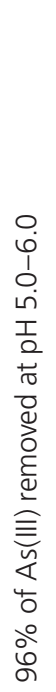 & 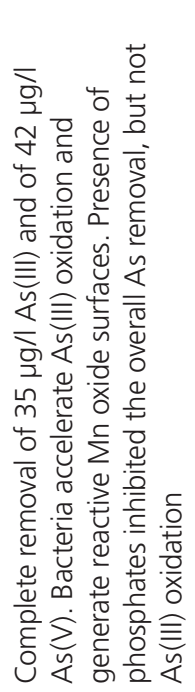 & 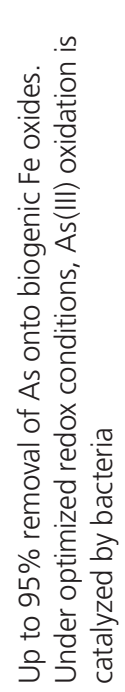 & 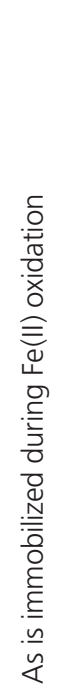 & 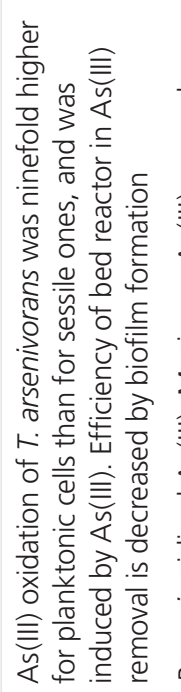 & 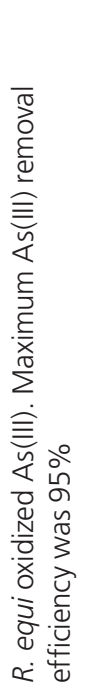 & 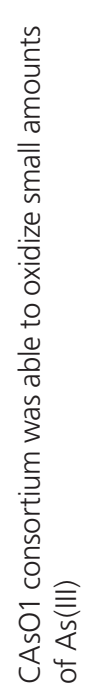 & 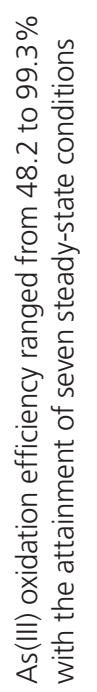 & 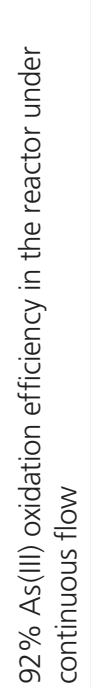 & 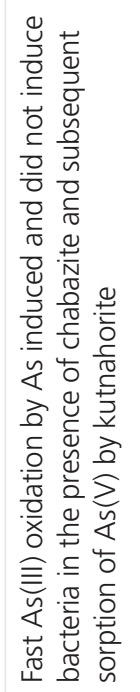 & 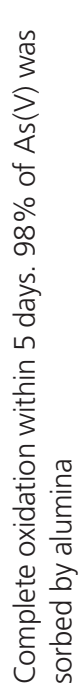 & 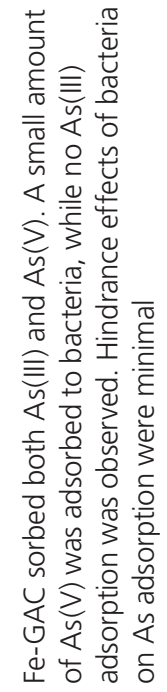 \\
\hline
\end{tabular}

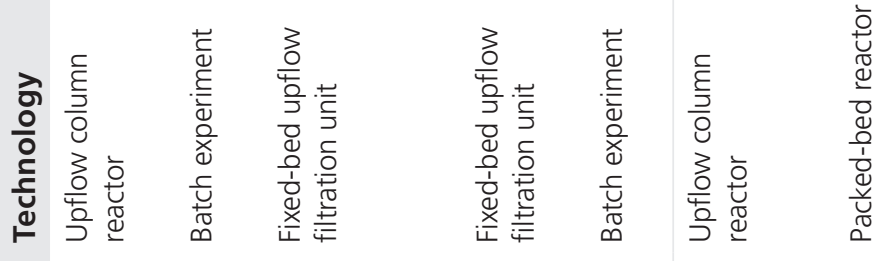

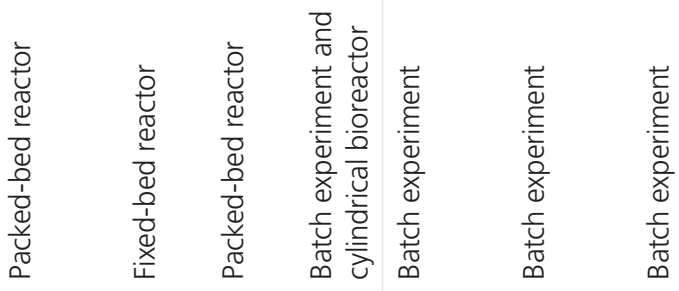
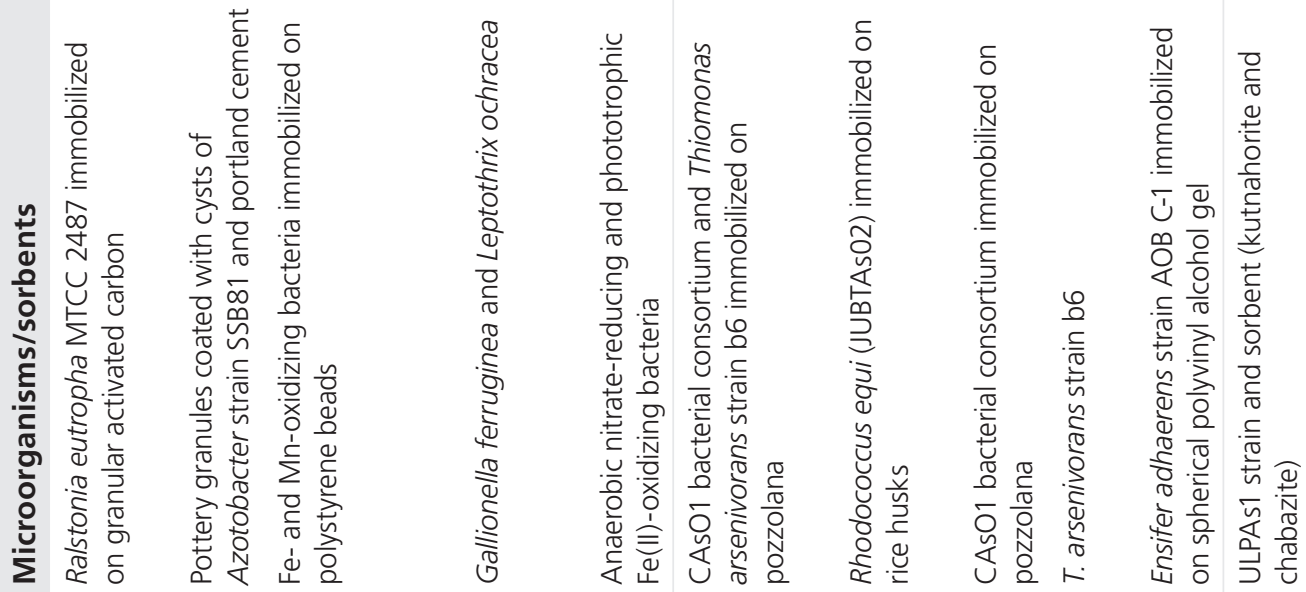

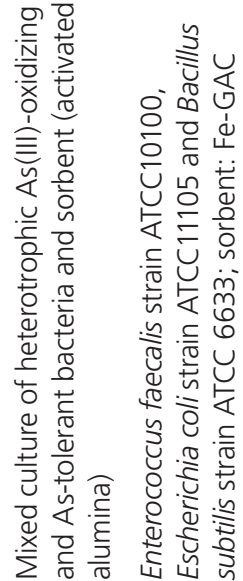

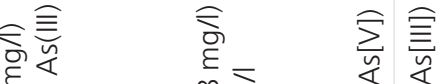

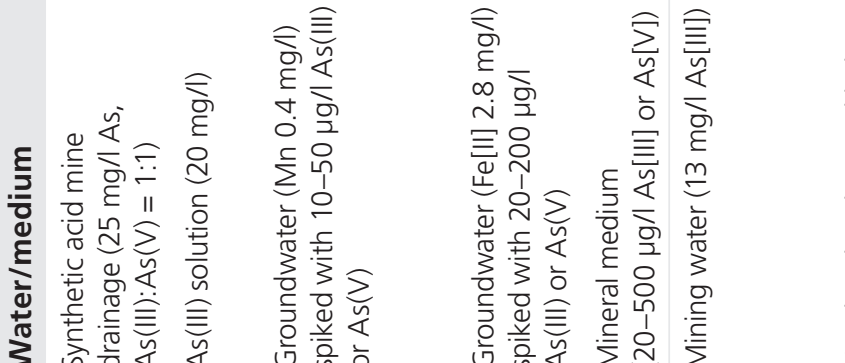

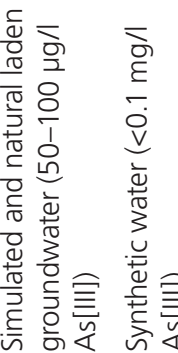
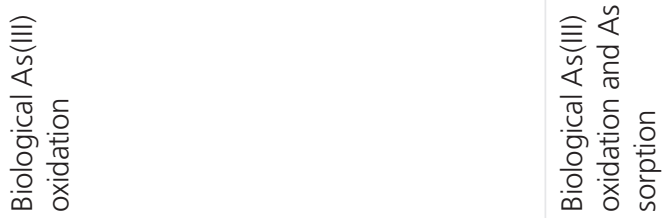
formation and activity of an As(III)-oxidizing biofilm developed by the $\mathrm{CAsO}$ 1 bacterial consortium in a bioreactor using pozzolana (volcanic material) as growth support. In particular, Michel and coauthors stated that the biofilm structure of both a consortium and a pure culture of $T$. arsenivorans was a physical barrier decreasing As(III) access to sessile cells and the induction of As(III) oxidase activity [103]. Nevertheless, they pointed out that the efficiency of the reactor needed to be enhanced by optimizing and controlling several parameters affecting biofilm formation, such as temperature and the addition of extracellular polymeric substances. Michon et al. showed that the $\mathrm{CAsO} 1$ consortium was able to oxidize not only in the range of the ' $\mathrm{mg} / \mathrm{l}$ order of magnitude', but also in the concentration scale of the ' $\mu \mathrm{g} / \mathrm{l}$ order of magnitude' [104].

After the biological oxidation of As(III), it is necessary to remove the produced $\mathrm{As}(\mathrm{V})$ by using sorbents. The combined processes of biological oxidation and chemical removal onto synthetic sorbents in one- and two-step processes have been investigated by several authors. In one of the first applications of this technique, Lièvremont et al. found that two mineral phases, kutnahorite and chabazite, showed different abilities in adsorbing arsenic after its biological oxidation and in performing abiotic oxidation [105]. Their results also showed that the studied bacterial strain performed a fast oxidation of As(III) at high arsenic concentrations in the presence of chabazite, and that $\mathrm{As}(\mathrm{V})$ was efficiently removed by kutnahorite. A two-phase detoxification process was therefore suggested.
By using a mixed culture of heterotrophic As(III) oxidizers, Ike et al. showed that arsenic removal by activated alumina was greatly enhanced by bacterial oxidation of As(III) to $\mathrm{As}(\mathrm{V})$, suggesting that the two processes must be performed consecutively for the attainment of optimum conditions in each step [106].

More recently, Wan and colleagues set up two reactors, one filled with sand and cells of T. arsenivorans, and the other with zero-valent iron (ZVI) [107]. The process was shown to be successful in terms of biological As(III) oxidation, and the chemical removal of arsenic was enhanced by ZVI, even though a decrease in adsorbing power was observed during the biological oxidation peak, probably due to biofilm formation on the ZVI surface and changes in the physicochemical conditions.

The possibility that arsenic-oxidizing bacteria have a negative effect on arsenic retention by sorbents can be related to the reactive microbial surfaces and to extracellular polymeric substances. Huang and coauthors highlighted the competitive interactions between phosphate and carboxylate groups of the cell surface of Shewanella putrefaciens, and $\mathrm{As}(\mathrm{V})$ was sorbed to goethite and ferrihydrite, leading to a mobilization of arsenic [108]. Conversely, Kim and coworkers reported only a minimal effect of a mixture of E. coli, Enterococcus faecalis and Bacillus subtilis on arsenic removal by iron-impregnated, granular-activated carbon [109].

\section{Future perspective}

Research on microbial transformations of arsenic is interesting both from a fundamental and an

\section{Executive summary}

\section{Arsenic \& health-related problems}

- Exposure to arsenic can cause dramatic health effects, such as 'arsenicosis' and cancer.

- WHO recommend a maximum concentration of arsenic in drinking water of $10 \mu \mathrm{g} / \mathrm{l}$.

\section{The microbiology of arsenic}

- Bacteria can cope with arsenic either by detoxification or by gaining energy from inorganic arsenic.

- Primordial, anoxic, arsenic-rich environments were colonized by bacteria that were able to oxidize arsenite into the less toxic arsenate, leading to partial detoxification of the inhospitable environment, and so allowing other microorganisms to proliferate.

- Arsenic is released in aquifers by reductive reactions catalyzed by different dissimilatory respiring microbes.

\section{Detection \& distribution of arsenic bacteria}

- Molecular markers involved in arsenic metabolism (i.e., aioA, arrA, ars $C$ and $\operatorname{arx} A$ ) are efficient at detecting arsenic bacteria and for studying their diversity, distribution and function.

\section{'Arsenomics'}

- The use of different 'omic' techniques on both pure cultures and microbial communities makes it possible to study the presence and expression of different genes involved in arsenic metabolism and detoxification in great detail.

\section{Arsenic removal from waters: the biological step}

- Bacterial oxidation of arsenite to the more easily sorbed arsenate is a promising approach for the treatment of contaminated water.

- The combination of bacterial oxidation and chemical adsorption is an efficient method of removing arsenic from polluted water. 
applied point of view. One of the topics that will certainly draw more attention is the origin and evolution of arsenic metabolism. Decreasing prices of DNA sequencing make it possible to sequence the genomes of many different bacterial strains and so to study the evolution of arsenic metabolism. In addition, next-generation sequencing will be used to sequence complete microbial communities from arsenic-contaminated environments, and to study the expression of genes in their constituting bacteria. The availability of this enormous amount of genomic data makes it possible to study microbial communities with a systems biology approach and, eventually, to predict their behavior under different environmental conditions [110,111].

In addition to curiosity-driven research, the removal of arsenic from contaminated groundwater, which is often used as a source of drinking water or for irrigation of crops, requires further research. Although pure culture experiments have shown good results regarding the removal of arsenic from groundwater, we strongly believe that large-scale purification can only be achieved with natural consortia. Pure cultures require sterile bioreactors and expensive substrates. In addition, these cultures might not be tolerant to the fluctuating composition of contaminated groundwater. Natural consortia, on the other hand, have been used for decades in the treatment of municipal waste water; they can be kept in open systems and consist of a suite of microbes that will be selected by environmental conditions. By tweaking these conditions, the performance of the process of interest can be drastically improved. So far, the microbes involved in these processes have been treated as a 'black-box', but today, with the use of next-generation sequencing and other high-throughput techniques, the direct or indirect roles of the microorganisms and their interactions can be ascertained in detail. Within these treatment processes, the combined use of microbes and adsorbents is of great interest.

\section{Financial \& competing interests disclosure}

Funding for this work was provided by the following grants: Fondazione CARIPLO (project 2010-2221) and PRIN (project 2010JBNLJ7_004). The authors have no other relevant affiliations or financial involvement with any organization or entity with a financial interest in or financial conflict with the subject matter or materials discussed in the manuscript apart from those disclosed.

No writing assistance was utilized in the production of this manuscript.

\section{Open Access}

This work is licensed under the Creative Commons Attribution-Non Commercial 3.0 Unported License. To view a copy of this license, visit http://creativecommons.org/licenses/by-nc-nd/3.0/

\section{References}

Papers of special note have been highlighted as:

- of interest

- of considerable interest

1. Mandal BK, Suzuki KT. Arsenic round the world: a review. Talanta 58(1), 201-235 (2002).

2. Oremland RS, Stolz JF. Arsenic, microbes and contaminated aquifers. Trends Microbiol. 13(2), 43-45 (2005).

3. Hossain MF. Arsenic contamination in Bangladesh - an overview. Agric. Ecosyst. Environ. 113(1-4), 1-16 (2006).

4. Dilda PJ, Hogg PJ. Arsenical-based cancer drugs. Cancer Treat. Rev. 33(6), 542-564 (2007).

5. Tchounwou PB, Centeno JA, Patlolla AK. Arsenic toxicity, mutagenesis, and carcinogenesis - a health risk assessment and management approach. Mol. Cell. Biochem. 255(1-2), 47-55 (2004).

- Discusses important aspects of arsenic toxicology and pathology at molecular and cellular levels.
6. Nordstrom DK. Worldwide occurrences of arsenic in ground water. Science 296(5576), 2143-2145 (2002).

7. WHO. Guidelines for Drinking Water Quality (Third Edition, Incorporating First and Second Addenda). WHO Press, Switzerland, 145-196 (2004).

8. Rhine ED, Phelps CD, Young LY. Anaerobic arsenite oxidation by novel denitrifying isolates. Environ. Microbiol. 8(5), 899-908 (2006).

9. Handley KM, Héry M, Lloyd JR. Redox cycling of arsenic by the hydrothermal marine bacterium Marinobacter santoriniensis. Environ. Microbiol. 11(6), 1601-1611 (2009).

10. Osborne TH, Jamieson HE, HudsonEdwards KA et al. Microbial oxidation of arsenite in a subartic environment: diversity of arsenite oxidase genes and identification of a psychrotolerant arsenite oxidizer. $B M C$ Microbiol. 10, 205 (2010).

11. Hoeft SE, Blum JS, Stolz JF et al. Alkalilimnicola ehrlichii sp nov., a novel, arsenite oxidizing haloalkalophylic gammaproteobacterium capable of chemoautotrophic or heterotrophic growth with nitrate or oxygen as the electron acceptor. Int. J. Syst. Evol. Microbiol. 57(Pt 3), 504-5012 (2007).

12. Kulp TR, Hoeft SE, Asao M et al. Arsenic(III) fuels anoxygenic photosynthesis in hot spring biofilms from Mono Lake, California. Science 321(5891), 967-970 (2008).

13. Zargar K, Hoeft S, Oremland R et al. Identification of a novel arsenite oxidase gene, $\operatorname{arx} A$, in the haloalkaliphilic, arseniteoxidizing bacterium Alkalilimnicola ehrlichii strain MLHE-1. J. Bacteriol. 192, 3755-3762 (2010).

- Presents genetic identification of a new 'type' of arsenite oxidase that fills the phylogenetic gap between the Arr and AioA clades of arsenic metabolic enzymes.

14. Zargar K, Conrad A, Bernick DL et al. ArxA, a new clade of arsenite oxidase within the DMSO reductase family of molybdenum oxidoreductases. Environ. Microbiol. 14(7), 1635-1645 (2012).

15. Hoeft SE, Kulp TR, Han S et al. Coupled arsenotrophy in a hot spring photosynthetic 
biofilm at Mono Lake, California. Appl. Environ. Microbiol. 76(14), 4633-4639 (2010).

- Presents a model system of anaerobic arsenic cycling in ecosystems and discusses the involvement of anoxygenic photosynthesis in primordial arsenic cycling.

16. Wolfe-Simon F, Blum JS, Kulp TR et al. A bacterium that can grow by using arsenic instead of phosphorus. Science 332(6034), 1163-1166 (2011).

- Controversial paper on a bacterium that substitutes arsenic for phosphorus.

17. Rosen BP, Liu Z. Transport pathways for arsenic and selenium: a miniriew. Environ. Int. 35(3), 512-515 (2009).

18. Rosen BP. Biochemistry of arsenic detoxification. FEBS Lett. 529(1), 86-92 (2002).

19. Paez-Espino D, Tamames J, de Lorenzo V et al. Microbial responses to environmental arsenic. Biometals 22(1), 117-130 (2009).

20. Hery M, Van Dongen BE, Gill F et al. Arsenic release and attenuation in low organic carbon aquifer sediments from west Bengal. Geobiology 8(2), 155-168 (2010).

21. Huang $\mathrm{Y}, \mathrm{Li} \mathrm{H}$, Rensing $\mathrm{C}$ et al. Genome sequence of the facultative anaerobic arseniteoxidizing and nitrate-reducing bacterium Acidovorax sp. strain NO1. J. Bacteriol. 196(6), 1635-1636 (2012).

22. Mailloux BJ, Alexandrova E, Keimowitz AR et al. Microbial mineral weathering for nutrient acquisition releases arsenic. Appl. Environ. Microbiol. 75(8), 2558-2565 (2009).

23. Couture RM, Sekowska A, Fang G et al. Linking selenium biogeochemistry to the sulfur-dependent biological detoxification of arsenic. Environ. Microbiol. 14(7), 1612-1623 (2012).

24. Fisher J, Hollibaugh JT. Selenate-dependent anaerobic arsenite oxidation by a bacterium from Mono Lake, California. Appl. Environ. Microbiol. 74, 2588-2594 (2008).

25. Budinoff C, Hollibaugh, JT. Arsenitedependant photoautotrophy by an Ectothiorhodospira-dominated consortium. ISME J. 2(3), 340-343 (2008).

26. vanden Hoven RN, Santini JM. Arsenite oxidation by the heterotroph Hydrogenophaga sp. str. NT-14: the arsenite oxidase and its physiological electron acceptor. Biochim. Biophys. Acta 1656(2-3), 148-155 (2004).

27. Lieutaud A, van Lis R, Duval S et al. Arsenite oxidase from Ralstonia sp. 22. J. Biol. Chem. 285, 20433-20441 (2010).

-. Discusses the sensitivity of Aro activity to sulfite and sulfide, which are substrates of the sox system. This paper reinforces the link between arsenite and sulfur oxidation.

28. Quéméneur M, Heinrich-Salmeron A, Muller $\mathrm{D}$ et al. Diversity surveys and evolutionary relationships of $a o x B$ genes in aerobic arseniteoxidizing bacteria. Appl. Environ. Microbiol. 74(14), 4567-4573 (2008).

29. Lett MC, Muller D, Lièvremont $\mathrm{D}$ et al. Unified nomenclature for genes involved in prokaryotic aerobic arsenite oxidation. J. Bacteriol. 194, 207-208. (2012).

30. Cai L, Liu G, Rensing C et al. Genes involved in arsenic transformation and resistance associated with different levels of arseniccontaminated soils. BMC Microbiol. 9, 4 (2009).

- Discusses the distribution of highly diverse arsenite-resistant microbial species in three soils with long-term arsenic contamination.

31. Cai L, Rensing C, Li X, Wang G. Novel gene clusters involved in arsenite oxidation and resistance in two arsenite oxidizers: Achromobactersp. SY8 and Pseudomonas sp. TS44. Appl. Microbiol. Biotechnol. 83(4), 715-725 (2009).

32. Chang JS, Yoon IH, Lee JH et al. Arsenic detoxification potential of aox genes in arsenite-oxidizing bacteria isolated from natural and constructed wetlands in the Republic of Korea. Environ. Geochem. Health 32(2), 95-105 (2010).

33. Duquesne K, Lieutaud A, Ratouchniak J et al. Arsenite oxidation by a chemoautotrophic moderately acidophilic Thiomonas sp.: from the strain isolation to the gene study. Environ. Microbiol. 10(1), 228-237 (2008).

34. Andreoni V, Zanchi R, Cavalca L et al. Arsenite oxidation in Ancylobacter dichloromethanicus As3-1b strain: detection of genes involved in arsenite oxidation and $\mathrm{CO}_{2}$ fixation. Curr. Microbiol. 65(2), 212-218 (2012).

35. Lebrun E, Brugna M, Baymann F et al. Arsenite oxidase, an ancient bioenergetic enzyme. Mol. Biol. Evol. 20, 686-693 (2003).

36. Ellis PJ, Conrads T, Hille R et al. Crystal structure of the $100 \mathrm{kDa}$ arsenite oxidase from Alcaligenes faecalis in two crystal forms at 1.64 A and 2.03 A. Structure 9(2), 125-132 (2001).

37. Kashyap DR, Botero LM, Franck WL et al. Complex regulation of arsenite oxidation in Agrobacterium tumefaciens. J. Bacteriol. 188(3), 1081-1088 (2006).

38. Slyemi D, Ratouchniak J, Bonnefoy V. Regulation of the arsenic oxidation encoding genes of a moderately acidophilic, facultative chemolithoautotrophic Thiomonas sp. Adv. Mater. Res. 20-21, 427-430 (2007).
39. Muller D, Médigue C, Koechler S et al. A tale of two oxidation states: bacterial colonization of arsenic-rich environments. PLoS Genetics 3(4), 518-530 (2007).

40. Branco R, Francisco R, Chung AP et al. Identification of an aox system that requires cytochrome $\mathrm{C}$ in the highly arsenic-resistant bacterium Ochrobactrum tritici SCII24. Appl. Environ. Microbiol. 75, 5141-5147 (2009).

41. Oremland RS, Saltikov CW, Wolfe-Simon F et al. Arsenic in the evolution of Earth and extraterrestrial ecosystems. Geomicrobiol. J. 26, 522-536 (2009).

42. Fisher J, Hollibaugh JT. Selenate-dependent anaerobic arsenite oxidation by a bacterium from Mono Lake, California. Appl. Environ. Microbiol. 74(9), 2588-2594 (2008).

43. Ordónez E, Letek M, Valbuena $\mathrm{N}$ et al. Analysis of genes involved in arsenic resistance in Corynebacterium glutamicum ATCC 13032. Appl. Environ. Microbiol. 71(10), 6206-6215 (2005).

44. Langner HW, Inskeep WP. Microbial reduction of arsenate in the presence of ferrihydrite. Environ. Sci. Technol. 34(15), 3131-3136 (2000).

45. Achour AR, Bauda P, Billard P. Diversity of arsenite transporter genes from arsenicresistant soil bacteria. Res. Microbiol. 158(2), 128-137 (2007).

46. Branco R, Chung AP, Morais PV. Sequencing and expression of two arsenic resistance operons with different functions in the highly arsenic-resistant strain Ochrobactrum tritici SCII24T. BMC Microbiol. 8, 95 (2008).

47. Afkar E, Lisak J, Saltikov CW et al. The respiratory arsenate reductase from Bacillus selenitireducens strain MLS10. FEMS Microbiol. Lett. 226, 107-112 (2003).

48. Blum JS, Han S, Lanoil B et al. Ecophysiology of 'Halarsenatibacter silvermanii' strain SLAS-1T, gen. nov., sp. nov., a facultative chemoautotrophic arsenate respirer from saltsaturated Searles Lake, California. Appl. Environ. Microbiol. 75(7), 1950-1960 (2009).

49. Malasarn D, Keeffe JK, Newman DK. Characterization of the arsenate respiratory reductase from Shewanella sp. strain ANA-3. J. Bacteriol. 190(1), 135-142 (2008).

50. Giloteaux L, Holmes DE, Williams KH et al. Characterization and transcription of arsenic respiration and resistance genes during in situ uranium bioremediation. ISME J. 7(2), 370-783 (2013).

- Demonstration of the involvement of Geobacter in the reduction and release of arsenic from sediments.

51. Santini JM, Stolz JF. Prokaryote arsenate and selenate reduction. In: Strict and Facultative 
Anaerobes: Medical and Environmental Importance. Nakano MM, Zuber P (Eds). Horizon Press, VA, USA, 239-249 (2004).

52. Sorokin DY, Tourova TP, Sukhacheva MV et al. Desulfuribacillus alkaliarsenatis gen. nov. sp. nov., a deep-lineage, obligately anaerobic, dissimilatory sulfur and arsenate-reducing, haloalkaliphilic representative of the order Bacillales from soda lakes. Extremophiles 16, 597-605 (2012).

53. Blum JS, Kulp TR, Han S et al. Desulfohalophilus alkaliarsenatis gen. nov., sp. nov., an extremely halophilic sulfate- and arsenate-respiring bacterium from Searles Lake, California. Extremophiles 16, 727-742 (2012).

54. Perez-Jimenez JR, DeFraia C, Young LY. Arsenate respiratory reductase gene ( $\operatorname{arr} A)$ for Desulfosporosinus sp. strain Y5. Biochem. Biophys. Res. Commun. 338, 825-829 (2005).

55. Liu A, Garcia-Dominguez E, Rhine ED et al. A novel arsenate respiring isolate that can utilize aromatic substrates. FEMS Microbiol. Ecol. 48, 323-332 (2004).

56. Richey C, Chovanec P, Hoeft SE et al. Respiratory arsenate reductase as a bidirectional enzyme. Biochem. Biophys. Res. Commun. 382, 298-302 (2009).

57. Saltikov CW, Wildman RA Jr, Newman DK. Expression dynamics of arsenic respiration and detoxification in Shewanella sp. strain ANA-3. J. Bacteriol. 187(2), 7390-7396 (2005).

58. Handley KM, Héry M, Lloyd JR. Marinobacter santoriniensis sp. nov., an arsenate-respiring and arsenite-oxidizing bacterium isolated from hydrothermal sediment. Int. J. Syst. Evol. Microbiol. 59, 886-892 (2009).

59. Gihring TM, Banfield JF. Arsenite oxidation and arsenate respiration by a new Thermus isolate. FEMS Microbiol. Lett. 204, 335-340 (2004).

60. Zobrist J, Dowdle PR, Davis JA et al. Mobilization of arsenite by dissimilatory reduction of adsorbed arsenate. Environ. Sci. Technol. 34, 4747-4753 (2000).

61. Malasarn D, Saltikov CW, Campbell KM et al. ArrA is a reliable marker for As $(\mathrm{V})$ respiration. Science 306, 455 (2004).

- Discusses the use of ArrA as a functional biomarker for monitoring arsenic reduction and mobilization in the environment.

62. Burkhardt EM, Akob DM, Bischoff S et al. Impact of biostimulated redox processes on metal dynamics in an iron-rich creek soil of a former uranium mining area. Environ. Sci. Technol. 44, 177-183 (2010).

63. Mumford AC, Barringer JL, Benzel WM et al. Microbial transformations of arsenic: mobilization from glauconitic sediments to water. Water Res. 46, 2859-2868 (2012).

64. Simeonova D, Lievremont D, Lagarde F et al. Microplate screening assay for detection of arsenite-oxidizing and arsenate-reducing bacteria. FEMS Microbiol. Lett. 237, 249-253 (2004).

65. Kuai L, Nair AA, Polz MF. Rapid and simple method for the most-probable-number estimation of arsenic-reducing bacteria. Appl. Environ. Microbiol. 67(7), 3168-3173 (2001).

66. Inskeep WP, Macur RE, Hamamura $\mathrm{N}$ et al. Detection, diversity and expression of aerobic bacterial arsenite oxidase genes. Environ. Microbiol. 9(4), 934-943 (2007).

67. Hamamura N, Macur RE, Korf S et al. Linking microbial oxidation of arsenic with detection and phylogenetic analysis of arsenite oxidase genes in diverse geothermal environments. Environ. Microbiol. 11(2), 421-431 (2009).

68. Quéméneur M, Cébron A, Billard P et al. Population structure and abundance of arsenite-oxidizing bacteria along an arsenic pollution gradient in waters of the upper isle River Basin, France. Appl. Environ. Microbiol. 76, 4566-4570 (2010).

69. Heinrich-Salmeron A, Cordi A, BrochierArmanet $C$ et al. Unsuspected diversity of arsenite-oxidizing bacteria as revealed by widespread distribution of the $a o x B$ gene in prokaryotes. Appl. Environ. Microbiol. 77(13), 4685-4692 (2011).

70. Sheik CS, Mitchell TW, Rizvi FZ et al. Exposure of soil microbial communities to chromium and arsenic alters their diversity and structure. PLoS ONE 7(6), e40059 (2012).

71. Sun Y, Polishchuk EA, Radoja U et al. Identification and quantification of $\operatorname{ars} C$ genes in environmental samples using real-time PCR. J. Microbiol. Meth. 58(3), 335-349 (2004).

72. Kaur S, Kamli MR, Ali A. Diversity of arsenate reductase genes ( $\operatorname{ars} C$ genes) from arsenic-resistant environmental isolates of E. coli. Curr. Microbiol. 59, 288-294 (2009).

73. Kulp TR, Hoeft SE, Miller LG et al. Dissimilatory arsenate and sulphate reduction in sediments of two hypersaline, arsenic-rich soda lakes: Mono and Searles Lakes, California. Appl. Environ. Microbiol. 72(10), 6514-6526 (2006).

74. Kulp TR, Han S, Saltikov C et al. Effects of imposed salinity gradients on dissimilatory arsenate-reduction, sulphate reduction, and other microbial processes in sediments from two California soda lakes. Appl. Environ. Microbiol. 73, 5130-5137 (2007).

75. Song B, Chyun E, Jaffé PR et al. Molecular methods to detect and monitor dissimilatory arsenate respiring bacteria (DARB) in sediments. FEMS Microbiol. Ecol. 68, 108-117 (2009).

76. Xiong J, Tu S, van Nostrand JD et al. Microbial communities and functional genes associated with soil arsenic contamination and the rhizosphere of the arsenichyperaccumulating plant Pteris vittata L. Appl. Environ. Microbiol. 76(21), 7277-7284 (2010).

77. He Z, Deng Y, Van Nostrand JD et al. GeoChip 3.0 as a high throughput tool for analyzing microbial communitiy structure, composition, and functional activity. ISME J. 4, 1167-1179 (2010).

78. Buffi N, Merulla D, Beutier J et al. Development of a microfluidics biosensor for agarose-bead immobilized Escherichia coli bioreporter cells for arsenite detection in aqueous samples. Lab Chip 11(14), 2369-2377 (2011).

79. Siddiki MSR, Kawakami Y, Ueda S et al. Solid phase biosensors for arsenic or cadmium composed of a trans factor and cis element complex. Sensors 11, 10063-10073 (2011).

80. Muller D, Simeonova DD, Riegel F et al. Herminiimonas arsenicooxydans sp. nov., a metalloresistant bacterium. Int. J. Syst. Evol. Microbiol. 56, 1765-1769 (2006).

81. Arsène-Ploetze F, Koechler S, Marchal M et al. Structure, function, and evolution of the Thiomonas spp. genome. PLoS Genetics 6(2), e1000859 (2010).

82. Li X, Hu Y, Gong J et al. Genome sequence of the highly efficient arsenite-oxidizing bacterium Achromobacter arsenitoxydans SY8. J. Bacteriol. 194(5), 1243-1244 (2012).

83. Lin $Y$, Fan H, Shigeri $Y$ et al. Draft genome sequence of Halomonas sp. strain HAL1, a moderately halophilicarsenite-oxidizing bacterium isolated from a gold-mine soil. J. Bacteriol. 194(1), 199-200 (2012).

84. Hao X, Lin Y, Johnstone L et al. Genome sequence of the arsenite-oxidizing strain Agrobacterium tumefaciens 5A. J. Bacteriol. 194(4), 903 (2012).

85. Srivastava S, Verma PC, Singh A et al. Isolation and characterization of Staphylococcus sp. strain NBRIEAG-8 from arsenic contaminated site of west Bengal. Appl. Microbiol. Biotechnol. 95(5), 1275-1291 (2012).

86. Bryan CG, Marchal M, Battaglia-Brunet F. Carbon and arsenic metabolism in Thiomonas strains: differences revealed diverse adaptation processes. BMC Microbiol. 9, 127 (2009).

87. Cleiss-Arnold J, Koechler S, Proux C. Temporal transcriptomic response during arsenic stress in Herminiimonas arsenicoxydans. Genomics 11, 709 (2010). 
88. Inskeep WP, Rusch DB, Jay ZJ et al. Metagenomes from high-temperature chemotrophic systems reveal geochemical controls on microbial community structure and function. PLoS ONE 5(3), e9773 (2010).

89. Halter D, Cordi A, Gribaldo S et al. Taxonomic and functional prokaryote diversity in mildly arsenic-contaminated sediments. Res. Microbiol. 162, 877-887 (2011).

90. Bertin PN, Heinrich-Salmeron A, Pelletier E et al. Metabolic diversity among main microorganisms inside an arsenic-rich ecosystem revealed by meta- and proteogenomics. ISME J. 5, 1735-1747 (2011).

91. Mondal P, Majumder CB, Mohanty B. Laboratory based approaches for arsenic remediation from contaminated water: recent developments. J. Hazard. Mater. 137(1), 464-479 (2006).

92. Vaclavikova M, Gallios GP, Hredzak S et al. Removal of arsenic from water streams: an overview of available techniques. Clean Techn. Environ. Policy 10, 89-95 (2008).

93. Gauri SS, Archanaa S, Mondal KC et al. Removal of arsenic from aqueous solution using pottery granules coated with cyst of Azotobacter and portland cement: characterization, kinetics and modelling. Bioresource Technol. 102, 6308-6312 (2011).

94. Mondal P, Majumder CB, Mohanty B. Treatment of arsenic contaminated water in a laboratory scale up-flow bio-column reactor. J. Hazard. Mater. 153, 136-145 (2008).

95. Wang $S$, Zhao X. On the potential of biological treatment for arsenic contaminated soils and groundwater. J. Environ. Manage. 90, 2367-2376 (2009).

- Comprehensive review of the biological treatments for arsenic-contaminated soil and groundwater.

96. Katsoyiannis IA, Zouboulis AI, Jekel M. Kinetics of bacterial As(III) oxidation and subsequent $\mathrm{As}(\mathrm{V})$ removal by sorption onto biogenic manganese oxides during groundwater treatment. Ind. Eng. Chem. Res. 43, 486-493 (2004).

97. Katsoyiannis IA, Zouboulis AI. Application of biological processes for the removal of arsenic from groundwaters. Water Res. 38, 17-26 (2004)

98. Newman DK, Beveridge TJ, Morel F. Precipitation of arsenic trisulfide by Desulfotomaculum auripigmentum. Appl. Environ. Microbiol. 63(5), 2022-2028 (1997).

99. Lee JH, Kim MG, Yoo B et al. Biogenic formation of photoactive arsenic-sulfide nanotubes by Shewanella sp. strain HN-41. Proc. Natl Acad. Sci. USA 104(51), 20410-20415 (2007).
100. Ito A, Miura JI, Ishikawa $\mathrm{N}$ et al. Biological oxidation of arsenite in synthetic groundwater using immobilised bacteria. Water Res. 46, 4825-4831 (2012).

101. Bag P, Bhattacharya P, Chowdhury R. Bio-detoxification of arsenic laden groundwater through a packed bed column of a continuous flow reactor using immobilized cells. Soil Sediment. Contam. 19, 455-466 (2010).

- Interesting paper on the use of meta-omics data to reconstruct metabolic pathways of different microorganisms in an arsenic-contaminated environment.

102. Dastidar A, Wang YT. Modeling arsenite oxidation by chemoautotrophic Thiomonas arsenivorans strain b6 in a packed-bed bioreactor. Sci. Total Environ. 432, 113-121 (2012).

103. Michel C, Jean M, Coulon S et al. Biofilms of As(III)-oxidising bacteria: formation and activity studies for bioremediation process development. Appl. Microbiol. Biotechnol.77, 457-467 (2007).

104. Michon J, Dagot C, Deluchat V et al. As(III) biological oxidation by $\mathrm{CAs} \mathrm{O} 1$ consortium in fixed-bed reactors. Process Biochem. 45, 171-178 (2010).

105. Lièvremont D, N'negue MA, Behra PH, Lett MC. Biological oxidation of arsenite: batch reactor experiments in presence of kutnahorite and chabazite. Chemosphere 51, 419-428 (2003).

106. Ike M, Miyazaki T, Yamamoto N et al. Removal of arsenic from groundwater by arsenite-oxidizing bacteria. Water Sci. Technol. 58(5), 1095-1100 (2008).

107. Wan J, Klein J, Simon S et al. AsIII oxidation by Thiomonas arsenivorans in up-flow fixedbed reactors coupled to As sequestration onto zero-valent iron-coated sand. Water Res. 44, 5098-5108 (2010).

108. Huang J-H, Elzinga EJ, Brechbuehl Y et al. Impacts of Shewanella putrefaciens strain $\mathrm{CN}-32$ cells and extracellular polymeric substances on the sorption of $\mathrm{As}(\mathrm{V})$ and As(III) on Fe(III)-(hydr)oxides. Environ. Sci. Technol. 45, 2804-2810 (2011).

109. Kim H-C, Lee C-G, Park J-A et al. Arsenic removal from water using iron-impregnated granular activated carbon in the presence of bacteria. J. Environ. Sci. Health A Tox. Hazard. Subst. Environ. Eng. 45, 177-182 (2010).

110. Raes J, Bork P. Molecular eco-systems biology: towards an understanding of community function. Nat. Rev. Microbiol. 6, 693-699 (2008).

111. Zengler K, Palsson BO. A road map for the development of community systems (CoSy) biology. Nat. Rev. Microbiol. 10, 366-372 (2012).

112. Rosen BP, Ajees AA, McDemott TR. Life and death with arsenic. Bioessays 33(5), 350-357 (2011).

113. Reaves ML, Sinha S, Rabinowitz JD et al. Absence of detectable arsenate in DNA from asrenate-grown GFAJ-1 cells. Science 337, 470-473 (2012).

114. Erb TJ, Kiefer P, Hattendorf B et al. GFAJ-1 is an arsenate-resistant, phosphate-dependent organism. Science 27, 467-470 (2012).

115. Gorra R, Webster G, Martin M et al. Dynamic microbial community associated with iron-arsenic co-precipitation products from a groundwater storage system in Bangladesh. Microbial Ecol. 64(1), 171-186 (2012).

116. Jareonmit P, Sajjaphan K, Sadowsky MJ. Structure and diversity of arsenic resistant bacteria in an old tin mine area of Thailand. J. Microbiol. Biotechnol. 20(1), 169-178 (2010).

117. Chen S, Shao Z. Isolation and diversity analysis of arsenite-resistant bacteria in communities enriched from deep-sea sediments of the southwest Indian Ocean Ridge. Extremeophiles 13, 39-48 (2009).

118. Sutton NB, van der Kraan GM, van Loosdrecht MC et al. Characterization of geochemical constituents and bacterial populations associated with arsenic mobilization in deep and shallow tube wells in Bangladesh. Water Res. 43(6), 1720-1730 (2009).

119. Connon SA, Koski AK, Neal AL et al. Ecophysiology and geochemistry of microbial arsenic oxidation within a high arsenic, circumneutral hot spring system of the Alvord Desert. FEMS Microbiol. Ecol. 64, 117-128 (2008).

120. Hetzer A, Morgan HW, McDonald IR et al. Microbial life in Champagne Pool, a geothermal spring in Waiotapa, New Zealand. Extremophiles 11, 605-614 (2007).

121. Bruneel O, Duran R, Casiot C et al. Diversity of microorganisms in $\mathrm{Fe}-\mathrm{As}$-rich acid mine drainage waters of Carnoulès, France. Appl. Environ. Microbiol. 72(1), 551-556 (2006).

122. Hohmann C, Winkler E, Morin G et al. Anaerobic Fe(II)-oxidizing bacteria show As resistance and immobilize As during Fe(III) mineral precipitation. Environ. Sci. Technol. 44, 94-101 (2010).

\section{Website}

201. Harvard University. Chronic arsenic poisoning: pictures of sufferers. http://users.physics.harvard.edu/-wilson/ arsenic/pictures/arsenic_project_pictures2. html 